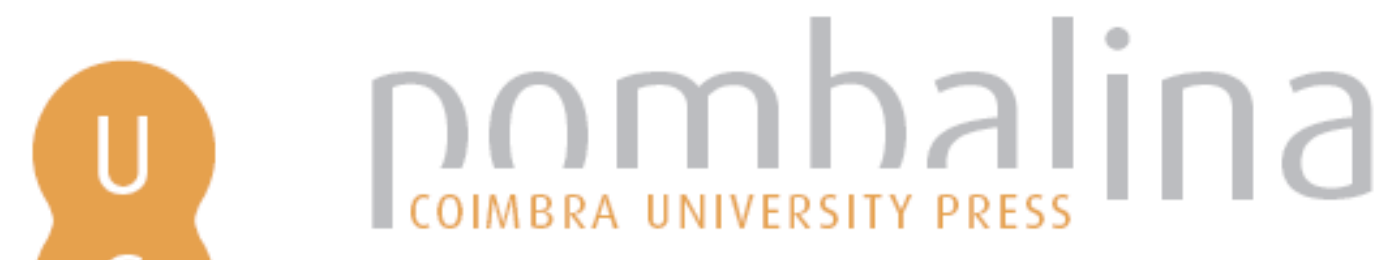

\title{
A homage to Professor Ruy Couceiro da Costa
}

Autor(es): $\quad$ Madeira, H. S. C.

Publicado por: Imprensa da Universidade de Coimbra

URL

persistente: URI:http://hdl.handle.net/10316.2/31307

DOI: $\quad$ DOI:http://dx.doi.org/10.14195/978-989-26-0240-0_2

Accessed : $\quad$ 26-Apr-2023 11:38:52

A navegação consulta e descarregamento dos títulos inseridos nas Bibliotecas Digitais UC Digitalis, UC Pombalina e UC Impactum, pressupõem a aceitação plena e sem reservas dos Termos e Condições de Uso destas Bibliotecas Digitais, disponíveis em https://digitalis.uc.pt/pt-pt/termos.

Conforme exposto nos referidos Termos e Condições de Uso, o descarregamento de títulos de acesso restrito requer uma licença válida de autorização devendo o utilizador aceder ao(s) documento(s) a partir de um endereço de IP da instituição detentora da supramencionada licença.

Ao utilizador é apenas permitido o descarregamento para uso pessoal, pelo que o emprego do(s) título(s) descarregado(s) para outro fim, designadamente comercial, carece de autorização do respetivo autor ou editor da obra.

Na medida em que todas as obras da UC Digitalis se encontram protegidas pelo Código do Direito de Autor e Direitos Conexos e demais legislação aplicável, toda a cópia, parcial ou total, deste documento, nos casos em que é legalmente admitida, deverá conter ou fazer-se acompanhar por este aviso. 
J. S. Redinha

J. da Providência

A. J. C. Varandas

Editors

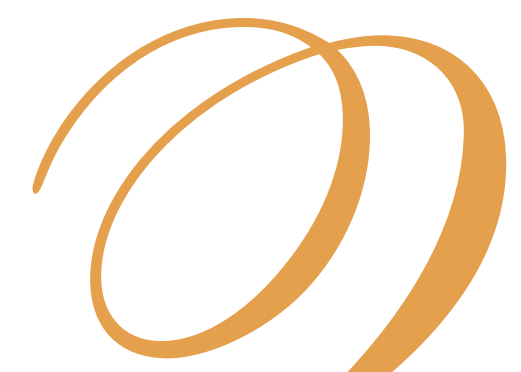

in Chemistry and Physics

A tribute to the memory of

Professor Couceiro da Costa

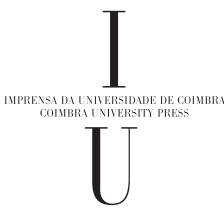




\title{
2. A Homage TO RuY COUCEIRO DA Costa
}

\author{
H. S. C. Madeira \\ University of Coimbra, Portugal
}

"Yo soy yo y mi circunstancia". In the words of Ortega y Gasset, if we look at the work and legacy of Professor Couceiro da Costa many decades after his departure, this implies that we understand his time and circumstances. Professor Couceiro da Costa was Professor of Chemistry in the University of Coimbra from 1925 to 1955 . It is not hard to imagine the difficulties and material deficiencies for teaching and research in Chemistry in the first decades of last century. Whilst it is certain that Professor Couceiro da Costa contributed to resolve these material problems, particularly during the almost two decades in which he was Director of the Department of Chemistry, his greatest contribution, seen from this distance, is to have to instilled in Coimbra the modern view of a University. He believed in Chemistry and Physics, and defended and practiced the view of the prime role of the creation of knowledge, through research and teaching of the most up-to-date problems, as the element which distinguishes the great Universities, while his action also contributed, through example, to the modernization of the University in other areas.

Time, the great evaluator, assures us that this belated tribute to Professor Couceiro da Costa is entirely fair and warranted. The Rectory of the University of Coimbra is pleased and proud to be associated with this initiative of the Academia de Ciências de Lisboa, proposed by three members of that illustrious Academy, all eminent Professors of the University of Coimbra: Professor José 
Simões Redinha, Professor João da Providência and Professor António Varandas. The form used for this tribute, through a meeting of distinguished scientists to debate current problems of "Quantal Aspects in Chemistry and Physics", subscribes to the attitude of modernity which Professor Couceiro da Costa cultivated, and which is seen as the great factor of progress through the scientific research at the vanguard of knowledge. The resulting production of this book, containing the communications presented and discussed in the meeting, provides the most long lasting form to pay tribute to Professor Couceiro da Costa, and to become aware of his pioneering role in the teaching of theoretical chemistry in Portugal.

It is always an act of greatness to recognize publicly the merit and contributions of others. However, it is also an act of humility, a clear manifestation, as we know that progress is a long chain of individual contributions. If looking back allows as to see clearly, as Professor Couceiro da Costa emphasized through his vision of a modern University which teaches and carries out research into the problems of its era, following his inspirational example it is good to look to the present and the future, and increasingly recognize at the appropriate time, the contributors who are around us. Science has, after all, through the peer group evaluation and recognition the guaranty of the quality of its results.

Prof. Henrique Santos do Carmo Madeira

Vice-Rector of the University of Coimbra 